\title{
Literature Review: Depresi Postpartum
}

\section{Literature Review: Postpartum Depression}

\author{
Retno Arienta Sari \\ Fakultas Kedokteran, Universitas Lampung, Indonesia
}

\section{ARTICLE INFO}

Article history:

Received date

22 Aug 2019

Revised date

24 Jan 2020

Accepted date

30 Apr 2020

Keywords:

Depression;

Mood disorder;

Mother;

Postpartum.

\section{Kata kunci:}

Depresi;

Gangguang mood;

Ibu;

Postpartum.

\begin{abstract}
ABSTRAK
Postpartum depression is a mood disorder that occurs after delivery. This disorder usually occurs around 2-6 weeks after giving birth. Research shows that the incidence of postpartum depression is 1 to 2 of 1000 births and that $25 \%$ of mothers who have just given birth experience severe postpartum depression and that in mothers giving birth to their next child around $20 \%$. Symptoms of postpartum depression include depressed mood, loss of interest or pleasure in the activity, impaired appetite, sleep disturbance, physical agitation or psychomotor slowdown, weakness, feeling useless, difficulty concentrating, even suicidal ideation. It is important to do an early diagnosis of postpartum depression to both prevent and make symptoms worse. Mothers with postpartum depression need to get broad and maximum management from various parties, including families, closest people, and health workers from multidisciplinary sciences. In its handling, non-pharmacological therapies can be given such as psychological therapy and changes in daily behavior and also pharmacological therapies that previously need to be consulted to doctors such as tricyclic antidepressant drugs (TCAs) to reduce symptoms of postpartum depression.
\end{abstract}

Depresi postpartum adalah suatu gangguan mood yang terjadi setelah melahirkan. Gangguan ini biasanya terjadi sekitar 2-6 minggu setelah melahirkan. Penelitian membuktikan bahwa angka kejadian depresi postpartum adalah 1 sampai 2 dari 1000 kelahiran dan $25 \%$ ibu yang baru pertama melahirkan mengalami depresi pasca melahirkan yang berat dan pada ibu yang melahirkan anak selanjutnya sekitar $20 \%$. Gejala dari depresi postpartum meliputi mood yang tertekan, hilangnya ketertarikan atau senang dalam beraktivitas, gangguan nafsu makan, gangguan tidur, agitasi fisik atau pelambatan psikomotor, lemah, merasa tidak berguna, susah konsentrasi, bahkan keinginan untuk bunuh diri. Penting dilakukan diagnosis dini depresi postpartum adalah untuk mencegah maupun memperparah gejala yang ditimbulkan. Ibu dengan depresi postpartum perlu mendapatkan penatalaksanaan secara luas dan maksimal dari berbagai pihak, meliputi keluarga, orang terdekat, dan tenaga kesehatan dari multidisiplin ilmu. Dalam penanganannya, dapat diberikan terapi non-farmakologis seperti terapi psikologis dan perubahan perilaku sehari-hari dan juga terapi farmakologis yang sebelumnya perlu dikkonsulkan ke dokter seperti obat golongan tricyclc antidepressant (TCAs) untuk mengurangi gejala dari depresi postpartum.

Corresponding Author:

Retno Arienta Sari

Fakultas Kedokteran, Universitas Lampung, Indonesia

Email: retnoarientaar@gmail.com

\section{PENDAHULUAN}

Masa kehamilan hingga saat melahiran merupakan suatu peristiwa kompleks yang berpengaruh bagi seorang ibu. Banyak perubahan yang dapat menyebabkan gangguan baik dari aspek fisik dan psikologikal. Perubahan tersebut dapat menjadi suatu depresi setelah melahirkan yang disebut depresi pasca melahirkan atau Postpartum Depression (Elvira, Ismail, Moegni, \& Herqutanto, 2013).

Depresi postpartum adalah suatu gangguan mood yang terjadi setelah melahirkan dan merefleksikan disregulasi psikologikal yang merupakan tanda dari gejala depresi mayor. (Pradnyana, Wayan Westa, \& Ratep, 2013) 
Gangguan mood ini biasanya terjadi 2-6 minggu setelah melahirkan dengan karakterististik yaitu perasaan depresi, kecemasan yang berlebihan, insomnia, dan perubahan berat badan (Ardiyanti \& Dinni, 2018).

Kondisi depresi postpartum merupakan suatu keadaan yang serius, dimana sebuah penelitian membuktikan bahwa $25 \%$ ibu yang baru pertama melahirkan mengalami depresi pasca melahirkan yang berat dan pada ibu yang melahirkan anak selanjutnya sekitar 20\% (Kusuma, 2017).

Angka kejadian depresi postpartum adalah 1 sampai 2 dari 1000 kelahiran dan sekitar 50 sampai $60 \%$ ibu mengalami depresi postpartum saat memiliki anak pertama, dan sekitar 50\% ibu yang mengalami postpartum tersebut memiliki riwayat keluarga dengan gangguan mood (Prayoga, Dira, Ayu, \& Wahyuni, 2016).

Angka prevalensi kejadian deresi postpartum secara global mencapai hingga 1015\%. Di negara seperti Malta, Malaysia, Austria, Denmark, dan Singapura, hanya ada sedikit laporan mengenai kejadian tersebut. Sementara itu di negara seperti Brazil, Afrika Selatan, Taiwan, Korea, Italia, dan Kosta Rika, laporan mengenai terjadinya gejala depresi postpartum cukup tinggi. Bahkan sebuah penelitian yang dilakukan di India, melibatkan 359 ibu primipara, didapatkan insiden depresi postpartum sebanyak 11\% (Motzfeldt, Andreasen, Pedersen, \& Pedersen, 2013).

Angka kejadian depresi postpartum di Asia cukup tinggi dan bervariasi antara antara 26-85\%. Sedangkan di Indonesia angka kejadian tersebut antara $50-70 \%$ dari wanita pasca persalinan. Penelitian di beberapa rumah sakit di Indonesia seperti di RSUP Haji Adam Malik, Medan tahun 2009 bahwa dari 50 ibu postpartum spontan dirawat inap sebanyak $16 \%$ mengalami depresi postpartum (Kurniasari \& Astuti, 2015). Pada tahun 2017 di RS KIA Sadewa Yogyakarta, kejadian depresi postpartum adalah sebanyak $7,7 \%$. Hal ini menandakan bahwa kejadian depresi postpartum perlu mendapatkan perhatian mengingat masih banyaknya insiden yang terjadi di berbagai daerah (Diniyah, 2017).

Seorang ibu yang mengalami gangguan depresi postpartum biasanya memiliki mood yang tertekan, hilangnya ketertarikan atau senang dalam beraktivitas, gangguan nafsu makan, gangguan tidur, agitasi fisik atau pelambatan psikomotor, lemah, merasa tidak berguna, susah konsentrasi, bahkan keinginan untuk bunuh diri (Roswiyani, 2010). Efek dari depresi postpartum ini tidak hanya terjadi pada ibu, namun bisa juga terjadi pada bayi dari ibu tersebut. Bayi akan mengalami keterlambatan dari berbagai aspek, baik dari segi kofnitif, psikologi, neurologi, dan motorik Bayi juga akan cenderung lebih rewel sebagai respon untuk mencari dan mendapatkan perhatian dari ibunya (American Academy of Pediatrics, American College of Obstetricians and Gynecologists., 2012).

Meninjau hal tersebut sangat penting dilakukan diagnosis dini untuk mencegah depresi postpartum maupun memanajemen ibu yang sudah terdiagnosis agar tidak semakin memperparah kondisinya. Diagnosis dan manajamen tersebut perlu dilakukan sejak dini terutama di negara berkembang karena besarnya jumlah populasi serta tingginya angka kesuburan (Burgut, Bener, Ghuloum, \& Sheikh, 2013).

\section{PEMBAHASAN}

\section{Definisi Depresi Postpartum}

Depresi postpartum merupakan gangguan mood yang terjadi setelah melahirkan. Gangguan ini merefleksikan disregulasi psikologikal yang merupakan tanda dari gejala-gejala depresi mayor (Kusuma, 2017). Depresi postpartum biasanya dialami oleh ibu setelah 4 minggu melahirkan. Tanda-tanda yang menyertainya adalah perasaan sedih, menurunnya suasana hati, kehilangan minat dalam kegiatan sehari-hari, peningkatan atau penurunan berat badan secara signifikan, merasa tidak berguna atau bersalah, kelelahan, penurunan konsentrasi bahkan ide bunuh diri. Pada kasus yang berat depresi dapat menjadi psikotik, dengan halusinasi, waham dan pikiran untuk membunuh bayi. Diketahui sekitar 20-40\% wanita melaporkan adanya suatu gangguan emosional atau disfungsi kognitif pada masa pascapersalinan (Nasri, Wibowo, \& Ghozali, 2017).

Dampak negatif dari depresi postpartum tidak hanya dialami oleh ibu, namun dapat berdampak pada anak dan keluarganya juga. Ibu yang mengalami depresi tersebut, minat dan ketertarikan terhadap bayinya dapat berkurang. Ibu menjadi kurang merespon dengan positif seperti pada saat bayinya menangis, tatapan matanya, ataupun gerakan tubuh. Akhirnya ibu yang mengalami depresi postpartum tidak mampu merawat bayinya secara optimal termasuk menjadi malas memberikan ASI secara langsung (Wahyuni, 2014). 


\section{Etiologi dan Faktor Risiko}

Penyebab depresi postpartum belum diketahui secara pasti, namun banyak penelitian dan pustaka yang menyebutkan penyebab gangguan tersebut dapat berasal dari faktor biologis maupun psikososial. Penurunan hormon progesteron yang signifikan dapat mempengaruhi suasana hati dari ibu. Perubahan itu terlihat dengan adanya gejala depresi seperti lemas dan lesu (Brockington, 2009).

Berbagai faktor fisiologis dan psikososial diteliti dapat menjadi penyebab dari depresi postpartum. Beberapa hal yang diduga menjadi etiologi depresi postpartum antara lain (Brummelte \& Galea, 2016):

\section{Neurologi postpartum}

Depresi postpartum secara mekanisme biologi berhubungan dengan adanya gangguan depresif mayor. Secara umum, depresi berintegritas dengan penyakit pada sirkuit neuron dengan ditandai adanya pengurangan volume otak. Pengurangan ini terjadi pada seseorang yang mengalami gejala depresi mayor. Semakin lama seseorang mengalami gejala tersebut, maka akan semakin berkurang volume otaknya. Jumlah yang berkurang yaitu protein otak yang berfungsi mencetuskan pertumbuhan neuron dan formasi sinaps. Adanya stres dan depresi dapat mengurangi jumlah protein otak tesebut. Penelitian juga menunjukkan bahwa setelah dilahirkannya plasenta pada saat persalinan maka kadar estrogen dan progesterone plasma dari sang ibu mulai turun secara drastis. Kedua hormon tersebut memilki efek neural pada konsentrasi psikologis. Maka dari itu, dengan adanya penurunan drastis dari hormon tersebut dapat berefek pada psikologis.

2. Gangguan Autoimun

Selama persalinan, seorang ibu terpapar berbagai antigen fetal. Suatu penelitian menduga bahwa akibat adanya paparan tersebut berefek pada kondisi psikologis ibu. Seorang ibu menjadi cenderung emosional yang diduga asalnya dari gangguan autoimun tersebut.

3. Gangguan Tidur dan Ritme Sikardian

Ketika seorang ibu melahirkan maka ia akan mengalami masa adaptasi untuk perannya yang baru. Dengan adanya peran baru tesebut, seorang ibu menjadi kekurangan waktu tidurnya karena harus menjaga bayinya. Aktivitas itu cenderung membuat ibu menjadi kelelahan atau fatigue sehingga bisa memicu terjadinya depresi. Kurangnya waktu tidur menyebabkan hormone tidur yang dihasilkan di kelenjar pineal otak menjadi berkurang. Hormon tersebut adalah hormon melatonin. Terganggunya produksi hormon tersebut merupakan kontributor terhadap depresi postpartum (Sharkey, Pearlstein, \& Carskadon, 2013).

Sebuah studi membuktikan bahwa ibu primipara atau ibu yang baru pertama kali melahirkan lebih banyak mengalami depresi postpartum. Hal tersebut terjadi karena ketidaksiapan ibu primipara secara psikologis dalam menghadapi kelahiran bayi lebih besar daripada ibu multipara atau yang sudah melahirkan lebih dari sekali. Ibu multipara sudah memilki pengalaman mengadapi kelahiran sebelumnya sehingga tidak stres dalam menyambut kelahiran anak tersebut (Soep, 2011).

Pada penelitian yang dilakukan oleh Kusuma, terdapat hubungan antara pekerjaan dengan kejadian depresi postpartum. Keadaan ibu yang harus kembali bekerja setelah melahirkan dapat memicu timbulnya depresi. Ibu yang tidak berhasil menyesuaikan diri dengan peran dan aktivitas barunya sebagai seorang ibu dapat mengalami gangguan psikologis atau depresi postpartum (Kusuma, 2017).

Menurut penelitan Kurniasari (2015, terdapat hubungan antara umur ibu, dengan kejadian depresi postpartum. Semakin muda usia ibu, maka akan semakin berisiko menimbulkan gangguan depresi postpartum. Hal ini dikarenakan usia yang muda cenderung tidak siap dalam perubahan perannya sebagai ibu, yaitu dalam kesiapan fisik, mental, finansial, dan juga sosial. Tidak hanya usia muda, namun usia yang terlalu tua juga dapat menjadi faktor risiko karena adanya faktor kelelahan dan keadaan anatomi tubuh yang sudah tidak baik lagi untuk hamil dan bersalin. Sementara itu, terdapat juga hubungan antara tingkat pendidikan ibu dan kejadian depresi. Ibu yang tingkat pendidikannya rendah akan mempunyai jumlah anak yang banyak dan kualitas dalam perawatan bayi juga tidak baik Kehamilan yang terjadi pada usia muda , biasanya terjadi pada perempuan yang putus sekolah. Semakin tinggi pendidikan ibu, maka akan semakin baik juga pengetahuannya karena akan banyak informasi yang didapat. Paritas juga berhubungan dengan risiko terjadinya depresi postpartum. Gangguan postpartum berkaitan dengan status paritas adalah riwayat obstetri pasien yang meliputi riwayat hamil sampai bersalin serta apakah ada komplikasi dari kehamilan dan persalinan sebelumnya dan terjadi lebih banyak pada wanita primipara. Wanita primpara rentan terjadi gangguan depresi karena setelah melahirkan wanita tersebut berada dalam 
proses adaptasi, yang pada mulanya hanya memikirkan diri sendiri namun begitu bayi lahir, jika ibu tidak siap dan paham akan peran barunya maka ibu menjadi bingung sementara bayinya harus tetap dirawat. Maka dari itu diperlukan juga adanya dukungan suami dalam menghadapi masa-masa adaptasi tersebut. Kurangnya dukungan suami yang dapat berisiko menimbulkan depresi pada ibu yang baru melahirkan. Dukungan suami yang dapat berupa perhatian, komunikasi dan hubungan emosional yang intim. Jika hal-hal tersebut tidak terjalin dengan baik, dapat menjadi faktor yang paling bermakna menjadi pemicu terjadinya depresi postpartum pada ibu (Kurniasari \& Astuti, 2015)

Selain itu, depresi postpartum juga dapat disebabkan oleh pengaruh dari jenis persalinan. Penelitian yang dilakukan oleh Ariyanti membuktikan bahwa ibu dengan persalinan bedah lebih banyak mengalami depresi postpartum dibandingkan dengan persalinan pervagina. Hal tersebut terjadi karena proses penyembuhan dari persalinan bedah memakan waktu yang cukup lama sehingga menghambat ibu untuk menjalani peran barunya (Ariyanti, Nurdiati, \& Astuti, 2016).

\section{Diagnosis}

Melahirkan, dilihat dari sudut pandang kedokteran psikologi, merupakan peristiwa kompleks dalam pengalaman seorang manusia. Ibu yang baru melahirkan rentan mengalami gangguan kejiwaan akibat pengaruh fisik dan perubahan psikologis saat melahirkan. Maka dari itu sangat penting untuk melakukan deteksi dan mendiagnosis dini dari depresi postpartum agar tidak terjadi hal yang lebih buruk (Brockington, 2009).

Evaluasi wanita dengan kemungkinan depresi postpartum membutuhkan anamnesis yang cermat untuk memastikan diagnosis, mengidentifikasi apakah ada gangguan lainnya, dan mengelola masalah medis dan psikososial yang terkontribusi didalamnya. Sekitar $70 \%$ dari ibu yang baru melahirkan memiliki gejala depresi ringan yang umumnya akan memuncak pada rentang 2 hinggan 5 hari setelah melahirkan. Gejala tersebut biasanya mulai mereda secara spontan dalam waktu 2 minggu, namun jika tidak terdeteksi dengan cepat dan terlambat ditangani, dapat berkembang menjadi depresi yang disebut depresi postpartum (Stewart \& Vigod, 2016).

Kriteria yang digunakan dalam skrining penegakkan diagnosis depresi postpartum dapat digunakan beberapa instrumen antara lain (Gjerdingen \& Yawn, 2007):
1. Schedule of Afective Disorders and Schizophrenia (SADS)

SADS terdiri dari beberapa pertanyaan terbuka yang berkaitan dengan gejala dengan penjajakan untuk pertanyaan berikutnya. Terdapat 11 gejala depresif dalam delapan kategori yaitu gangguan makan, gangguan tidur, kelelahan, kurang semangat, perasaan bersalah, gangguan konsentrasi, keinginan bunuh diri, dan gangguan motorik. Setiap gejala tersebut diberi skor 1-6 oleh pemeriksa dengan skor minimal 3 (ringan) pada setiap gejalanya. Gejala tersebut harus minimal terjadi selama 2 minggu.

2. Structured Clinical Interview for DSM-IV-R (SCID)

SCID merupakan wawancara berbasis klinis yang menggabungkan kriteria diagnosis DSM-IV dan memiliki versi berbeda yang digunakan untuk pasian rawat inap, rawat jalan, hingga yang bukan populasi klinis. Instrumen ini terdiri dari enam modul yang memerlukan 45-60 menit untuk melengkapinya.

3. Standard Psychiatric Interview (SPI)

SPI merupakan wawancara yang digunakan bukan untuk individu, namun survey komunitas. Instrumen ini terdiri dari 10 gejala psikiatrik.

4. Present State Examination (PSE)

PSE merupakan wawancara yang digunakan untuk mencari gejala yang terjadi 4 minggu sebelum dilakukan wawancara tersebut. Biasanya instrumen ini digunakan untuk studi dan penelitian mengenai depresi postpartum.

5. Hamilton Rating Scale for Depression (HSRD)

HSRD adalah instrumen untuk menilai keparahan depresi bagi pasien yang sudah terdiagnosa. Terdiri dari 17 gejala depresi dan sering digunakan pada beberapa literatur yang membahaas depresi postpartum.

6. Edinburgh Postnatal Depression Scale (EDPS)

EDPS adalah instrument yang berupa kuisioner 10 item yang mudah dijalankan, dan merupakan alat skrining yang efektif dan spesifik untuk menskrining depresi postpartum secara internasonal. Dari 10 pertanyaan tersebut, masing-masing pertanyaan memiliki nilai 1-3, dengan skor total maksimal 30 poin. Jika seorang perempuan mendapatkan poin 10 atau lebih dan memiliki pikiran untuk membahayakan diri sendiri maupun bayinya, maka diperlukan wawancara lebih lanjut dengan psikiater untuk melihat gejala dan menentukan diagnosis. 
Pada umumnya, perempuan yang mendapatkan hasil EPDS antara 5-9 dengan gejala depresi tanpa ide bunuh diri harus dievaluasi kembali 2-4 minggu setelah tes dilakukan (Gondo, 2012).

Instrumen skrining tersebut memiliki kelebihan dan kekurangan masing-masing dalam menegakan diagnosis depresi postpartum. Instrumen yang sering digunakan dalam penegakan diagnosis adalah EDPS. Sementara untuk yang lainnya lebih sering digunakan dalam penelitian dan studi mengenai depresi postpartum.

Selain instrumen yang telah disebutkan di atas, dapat juga digunakan Pedoman Penggolongan dan Diagnosis Gangguan Jiwa di Indonesia edisi III (PPDGJ-III) skrining gangguan depresi postpartum. Pada kriteria tersebut, depresi postpartum merupakan gangguan jiwa yang berhubungan dengan masa nifas (tidak lebih dari 6 minggu setelah persalinan), yang tidak memenuhi kriteria di tempat lain, serta memenuhi kriteria episode depresi. Adapun episode depresi tersebut seperti afek depresif, kehilangan minat, mudah lelah, berkurangnya konsentrasi, terganggunya waktu tidur, dan nafsu makan berkurang. Episode tersebut terjadi sekurang-kurangnya selama dua minggu (Maslim, 2013).

Sedangkan pada kriteria Diagnostic And Statisctical Manual of Mental Disorders, edisi keempat (DSM-IV) dan juga dibantu oleh uji Edinburgh Postnatal Depression Scale (EPDS), ibu dengan gejala depresi postpartum didefinisikan dengan beberapa gejala mayor, di mana salah satunya harus ada mood yang tertekan atau penurunan kesenangan. Gejala tersebut antara lain gangguan nafsu makan, agitasi fisik atau pelambatan psikomotor, lemah, menurunnya konsentrasi, dan adanya keinginan bunuh diri. Ibu juga sering merasakan insomnia meskipun bayinya telah tertidur. Gejala-gejala tersebut harus ada sepanjang hari dan terjadi seminimalnya selama dua minggu (Guze, 2014).

\section{Penatalaksanaan}

Wanita yang mengalami depresi yang tidak diobati selama kehamilan memiliki risiko tujuh kali lipat mengalami depresi postpartum dari wanita yang tidak memiliki gejala depresi antenatal; oleh karena itu, pengobatan depresi antenatal penting untuk pencegahan depresi pascapersalinan. Dalam satu penelitian observasional kecil yang melibatkan 78 wanita yang menerima diagnosis depresi pada trimester pertama kehamilan, depresi pascapersalinan tidak terjadi pada semua wanita yang mengalami depresi diobati dengan baik psikoterapi atau farmakoterapi, dibandingkan dengan 92\% wanita dengan depresi yang tidak diobati. Intervensi suportif dan psikologis lebih efektif ketika dilakukan setelah melahirkan dibandingkan saat mereka diinisiasi selama kehamilan Nutrisi yang sehat, oalhraga teratur, dan tidur yang cukup juga dianjurkan, meskipun bukti untuk mengurangi risiko depresi pascapersalinan atas faktor-faktor dasar ini masih terbatas (Stewart \& Vigod, 2016).

Dalam menatalaksana ibu dengan depresi postpartum, butuh penanganan secara luas baik dengan diberikannya terrapin non-farmakologis dan farmakologis. Melalui terapi nonfarmakologis, yaitu terapi psikologis, ibu dapat menemukan cara tepat untuk menghadapi gejala depresi tersebut, mengatasi gangguan yang muncul, atau berpikir positif ketika situasi sedang tertekan (Pearlstein, Howard, Salisbury, \& Zlotnick, 2009).

Tatalaksana dalam perawatan depresi postpartum bervariasi tergantung dengan tingkat keparahan dari gejalanya, termasuk kemampuannya untuk merawat dan berinteraksi dengan bayu yang baru lahir. Jika baru terjadi gejala ringan atau sedang maka dapat dikelola dalam perawatan primer terdekat namun lebih baik jika langsung dirujuk ke bagian psikiatrik untuk mencegah komplikasi yang lebih parah, terutama ketika ibu sudah memiliki pikiran untuk mencelakai atau membahayakan diri sendiri dan orang lain. Namun dalam melakukan perawatan depresi postpartum dapat terjadi beberapa kendala bagi sebagian orang, seperti masalah keuangan, transportasi, dan penitipan anak. Untuk wanita dengan gejala ringan, intervensi psikososial yang dapat diberikan contohnya ialah meningkatkan dukungan, seperti dukungan dari teman sebaya dan konseling yang dilakukan oleh praktisi kesehatan yang professional. Intervensi tersebut merupakan lini pertama dalam perawatan depresi postpartum. Sebuah penelitian metaanalisis menunjukkan bahwa wanita yang dirawat dengan intervensi psikososial lebih kecil memungkinannya untuk tetap depresi pada 1 tahun postpartum dibandingkan wanita yang hanya menerima perawatan standar di layanan primer. Untuk wanita dengan gejala penyakit sedang, dan untuk mereka dengan gejala penyakit ringan yang tidak dapat merespon intervensi psikososial saja, dapat direkomendasikan untuk mendapatkan psikoterapi formal seperti terapi perilaku kognitif dan terapi interpersonal. Terapi ini diberikan secara berkelompok maupun individu dalam kurun waktu 12 hingga 16 
minggu. Terapi perilaku kognitif berfokus pada perubahan pola pikir maladaptif, perilaku, atau keduanya, untuk menghasilkan perubahan positif dalam keadaan emosional. Sementara itu, terapi interpersonal adalah terapi suasana hati untuk hubungan interpersonal dan berfokus pada peningkatan hubungan untuk membantu dengan transisi peran seorang wanita menjadi orang tua baru (Stewart \& Vigod, 2016).

Seorang ibu yang mengalami depresi jangan segan untuk selalu menceritakan segala keluh kesahnya kepada keluarga atau orang lain yang dapat mengerti dan bisa membantu. Selain itu, istirahat yang cukup juga diperlukan agar dapat menghindari diri dari perasaan depresi akibat kelelahan, misalnya dengan meminta bantuan orang lain yang dapat dipercaya untuk bergantian mengurusi bayi. Dari segi pola makan, harus diberikan secara teratur dengan menu yang sehat dan seimbang diikuti olahraga ringan agar mood dapat membaik (Guille, Newman, Fryml, Lifton, \& Epperson, 2013)

Jika sudah dilakukan terapi perilaku kognitif dan interpersonal maupun terapi nonfarmakologis namun tidak berhasil, maka dapat diberikan terapi farmakologi. Terapi ini juga dapat diberikan jika penderita depresi postpartum lebih menyukai obat-obatan daripada terapi perilaku. Antidepresan yang dianggap dapat berkompatibel dengan ibu menyusui harus diresepkan oleh psikiater. Selain antidepresan, biasanya dapat juga diberikan sertraline. Untuk ibu depresi postpartum yang sedang menyusui biasanya diberikan pengobatan dengan dosis 50 mg setiap harinya selama 1 minggu. Setelah itu, di evaluasi kembali dan dilihat efek samping dari obat tersebut. Jika masih ada keinginan untuk membahayakan diri sendiri dan orang lain, maka ditambahkan dosis sesuai dengan kebutuhan (misalnya ditambah $50 \mathrm{mg}$ setiap 2 minggu dengan dosis harian maksimal $200 \mathrm{mg}$ hingga tercapainya remisi dengan sempurna. Terapi farmakologi umumnya dilanjutkan 6 hingga 12 bulan setelah remisi sempurna untuk mengurangi risiko kekambuhan. Jika gejala-gejala masih berulang dan terus mengalami kekambuhan maka disarankan untuk berkonsultasi kembali dengan spsikiater dan mendapatkan perawatan intensif kembali (Stewart \& Vigod, 2016).

Namun bagi ibu yang menderita depresi postpartum yang cukup parah, sebaiknya melakukan kunjungan ke dokter agar dapat diberikan terapi farmakologis seperti golongan tricyclc antidepressant (TCAs). Terapi ini akan meringankan gejala-gejala dari depresi postpartum sehingga dapat menjalani kegiatan sehari-hari secara normal (Guille, et al., 2013)

Keanekaragaman gejala dari depresi postpartum, risiko terhadap bayi, dan keterampilan dari sumber daya yang dibutuhkan, maka sangat dibutuhkan pelayanan rawat inap yang terspesialisasi untuk gejala tersebut. Diperlukan adanya layanan ibu dan anak dari tenaga medis yang berasal dari multidisiplin ilmu, termasuk psikiater, psikolog, perawat, dan juga tenaga sosial. Dimana tujuannya adalah untuk pencegahan, diagnosis dini, dan intervensi, dengan gangguan keluarga yang minimal. Dengan adanya tim yang mendukung tersebut, ibu yang mengalami depresi postpartum dapat terlayani dan termanajemen dengan baik. (Brockington, 2009).

\section{SIMPULAN}

Pentingnya dilakukan diagnosis dini depresi postpartum adalah untuk mencegah maupun memperparah gejala yang ditimbulkan. Banyak instrumen yang dapat digunakan untuk skrining dalam penegakan diagnosis depresi postpartum, salah satunya yang paling efektif yaitu instrument EDPS. Ibu dengan depresi postpartum perlu mendapatkan penatalaksanaan secara luas dan maksimal dari berbagai pihak, meliputi keluarga, orang terdekat, dan tenaga kesehatan dari multidisiplin ilmu. Dalam penanganannya, dapat diberikan terapi nonfarmakologis seperti terapi psikologis dan perubahan perilaku sehari-hari dan juga terapi farmakologis seperti obat golongan tricyclc antidepressant (TCAs) yang sebelumnya dikonsulkan ke dokter.

Ardiyanti, D., \& Dinni, S. M. (2018). Aplikasi Model Rasch dalam Pengembangan Instrumen Deteksi Dini Postpartum Depression. Jurnal Psikologi, 45(2), 81. https://doi.org/10.22146/jpsi.29818

Ariyanti, R., Nurdiati, D. S., \& Astuti, D. A. 
(2016). Pengaruh Jenis Persalinan Terhadap Risiko Depresi Postpartum. Jurnal Kesehatan Samodra Ilmu, 7(2), 98105.

Brockington, I. (2009). Diagnosis and management of post-partum disorders: a review. World Psychiatry: Official Journal of the World Psychiatric Association (WPA), 3(2), 89-95. Retrieved from

http://www.ncbi.nlm.nih.gov/pubmed/1663 3463\%0Ahttp://www.pubmedcentral.nih.g ov/articlerender.fcgi?artid=PMC1414675

Brummelte, S., \& Galea, L. A. M. (2016). Postpartum depression: Etiology, treatment and consequences for maternal care. Hormones and Behavior, 77, 153-166. https://doi.org/10.1016/j.yhbeh.2015.08.00 8

Burgut, F. T., Bener, A., Ghuloum, S., \& Sheikh, J. (2013). A study of postpartum depression and maternal risk factors in Qatar. Journal of Psychosomatic Obstetrics and Gynecology. https://doi.org/10.3109/0167482X.2013.78 6036

Diniyah, K. (2017). Gambaran depresi postpartum di rskia sadewa. Media Ilmu Kesehatan, 6(2), 162-167.

Elvira, S. D., Ismail, R. I., Moegni, F., \& Herqutanto. (2013). Deteksi, Pencegahan dan Tata Laksana Depresi pada Ibu Hamil dan Pascapersalinan. Majalah Kedokteran Indonesia, 63, 207-212.

Gjerdingen, D. K., \& Yawn, B. P. (2007). Postpartum depression screening: Importance, methods, barriers, and recommendations for practice. Journal of the American Board of Family Medicine, 20(3), 280-288. https://doi.org/10.3122/jabfm.2007.03.060 171

Gondo, H. K. (2012). Skrining Edinburgh Postnatal Depression Scale (EPDS) Pada Postpartum Blues. Jurnal Ilmiah Kedokteran, 1(2), 17-29.

Guille, C., Newman, R., Fryml, L. D., Lifton, C. K., \& Epperson, C. N. (2013). Management of postpartum depression. Journal of Midwifery and Women's Health. https://doi.org/10.1111/jmwh.12104

Guze, S. B. (2014). Diagnostic and Statistical Manual of Mental Disorders, 4th ed. (DSM-IV). American Journal of Psychiatry. https://doi.org/10.1176/ajp.152.8.1228
Kurniasari, D., \& Astuti, Y. A. (2015). Hubungan Antara Karakteristik Ibu, Kondisi Bayi dan Dukungan Sosial Suami dengan Postpartum Blues pada Ibu Dengan Persalinan SC di Rumah Sakit Umum Ahmad Yani Metro Tahun 2014. Jurnal Kesehatan Holistik, 9(3), 115-125.

Kusuma, P. D. (2017). Karakteristik Penyebab Terjadinya Depresi Postpartum pada Primipara dan Multipara. Jurnal Keperawatan Notokusumo, 5(1), 36-45.

Maslim, R. (2013). Diagnosis Gangguan Jiwa Rujukan Ringkas dari PPDGJ - III dan DSM - 5. In Diagnosis Gangguan Jiwa Rujukan Ringkas dari PPDGJ - III dan DSM - 5.

Motzfeldt, I., Andreasen, S., Pedersen, A. L., \& Pedersen, M. L. (2013). Prevalence of postpartum depression in Nuuk, Greenland - A cross-sectional study using Edinburgh Postnatal Depression Scale. International Journal of Circumpolar Health. https://doi.org/10.3402/ijch.v72i0.21114

Nasri, Z., Wibowo, A., \& Ghozali, E. W. (2017). Faktor Determinan Depresi Postpartum di Kabupaten Lombok Timur. Biuletin Penelitian Sistem Kesehatan, 20(3), 89-95.

Pearlstein, T., Howard, M., Salisbury, A., \& Zlotnick, C. (2009). Postpartum Depression. American Journal of Obstetrics and Gynecology, 200(4), 357364.

https://doi.org/10.1016/j.ajog.2008.11.033. Postpartum

Pradnyana, E., Wayan Westa, \& Ratep, N. (2013). Diagnosis Dan Tata Laksana Depresi Postpartum Pada Primipara. Rumah Sakit Umum Pusat Sanglah, 1-16.

Prayoga, I. K., Dira, A., Ayu, A., \& Wahyuni, S. (2016). Prevalensi dan Faktor Risiko Depresi Postpartum Di Kota Denpasar Menggunakan EPDS. E-Jurnal Medika, 5(7), 5-9.

Roswiyani. (2010). Post-partum depression. In Pharmaceutical and Biological Evaluations (Vol. 3, pp. 450-455).

Sharkey, K. M., Pearlstein, T. B., \& Carskadon, M. A. (2013). Circadian phase shifts and mood across the perinatal period in women with a history of major depressive disorder: A preliminary communication. Journal of Affective Disorders. https://doi.org/10.1016/j.jad.2013.04.046

Soep, S. (2011). Penerapan Edinburgh PostPartum Depression Scale Sebagai Alat Deteksi Risiko Depresi Nifas pada Primipara dan Multipara. Jurnal 
Keperawatan Indonesia, 14(2), 95-100. https://doi.org/10.7454/jki.v14i2.315

Stewart, D. E., \& Vigod, S. (2016). Postpartum Depression. New England Journal of Medicine, 375(22), 2177-2186.
https://doi.org/10.1056/NEJMcp1607649 Wahyuni, S. M. S. (2014). Faktor Internal dan Eksternal yang Mempengaruhi Depresi Postpartum. Jurnal Terpadu Ilmu Kesehatan, 3(2), 131-137. 